\title{
Efektivitas Komite dan Mekanisme Tata Kelola Perusahaan terhadap Pencegahan Kejahatan Keuangan
}

\author{
Alice $^{1}$, Natalis Christian ${ }^{2}$ \\ Universitas Internasional Batam ${ }^{1,2}$ \\ 1842121.alice@uib.edu, natalis.christian@uib.ac.id
}

\begin{abstract}
*Penulis Korespondensi
Diajukan : : 16 Nopember 2021

Disetujui : :27 Nopember 2021

Dipublikasi : 1 Januari 2022
\end{abstract}

\begin{abstract}
The research objectives of this study are to analyze the effectiveness of committee and mechanism of corporate governance to prevent financial crime. Financial Crime often occur inside the company, especially in Indonesia. Financial crime covers fraud, money laundering, bribe, corruption, terrorist financing and so on. At 2018, there's case where PT. Garuda Indonesia committed revenue recognition fraud by recognizing revenue amounted to USD 239 million from Mahata Aero Teknologi which is yet to be received by the end of 2018. The company's management and external audit are fined for the negligent in preventing the fraud. Therefore, the effectiveness of company's organizational structure played a big role to supervise and prevent the occurrence of financial crimes. In this discussion, the author investigates the effectiveness of audit committee, board of commissioners, stand-alone risk committee, external audit, effect of managerial ownership and company's performance toward financial crime. Data for the research were collected from secondary data found in annual report of 426 companies and analyzed using logistic regression method using SPSS 25. The study findings prove that stand-alone risk committee, external audit, and company's performance have a significant negative effect toward financial crime, while size of audit committee have a significant positive effect toward financial crime. Research show that meeting frequency of audit committee, board of commissioners, and managerial ownership has no significant effect toward financial crime.
\end{abstract}

Keywords: Audit Committee; Corporate Governance; Financial Crime; Stand-Alone Risk Committee

\section{PENDAHULUAN}

Kejahatan keuangan tidak mendapatkan banyak perhatian dari publik, namun hal tersebut memiliki dampak yang besar dan dapat mengancam stabilitas terhadap ekonomi dunia. Kejahatan Keuangan dapat terjadi dalam berbagai bentuk. Kejahatan keuangan korporasi yang paling umum terjadi biasanya adalah pencucian uang, pendanaan terorisme, fraud, penghindaran pajak, korupsi, penyuapan dan lainlain (Abdullah \& Said, 2019). Pada tahun 2019, organisasi anti-fraud yaitu Association of Certified Fraud Examiners (ACFE) melakukan survei terhadap 239 responden. Hasil survei menunjukan bahwa sebanyak sebesar 64,4\% atau 154 responden dari 239 responden memilih bahwa jenis fraud yang paling sering terjadi di Indonesia adalam dalam bentuk korupsi (ACFE, 2019). Kasus kejahatan keuangan yang terjadi pada perusahaan Bursa Efek Indonesia (BEI) adalah PT. Garuda Indonesai Tbk (Rusmana \& Tanjung, 2019). PT Garuda Indonesia melakukan kejahatan keuangan korporasi dalam bentuk revenue shenanigans ke-1 dimana adanya pencepatan pengakuan pendapatan sebelum waktunya. Garuda Indonesia mengakui pendapatan sebesar USD 239 juta dari Mahata Aero Teknologi yang seharusnya belum diterima hingga akhir tahun 2018 (Junnestine \& Christian, 2021). Garuda Indonesia tidak memenuhi kriteria pengakuan pendapatan sebagaimana tercantum dalam PSAK 23 mengenai pendapatan pada paragraf 28, paragraf 29, dan paragraf 30 dimana manfaat ekonomi akan diterima oleh entitas, dan jumlah pendapatatan dapat diukur secara andal (Wahyu Vitaningsih et al., 2020a) karena garuda dan Mahata belum memiliki kontrak yang mendetail terkait transaksi yang dilakukan (Wahyu Vitaningsih et al., 2020b). 
PT. Garuda Indonesia telah melakukan kecurangan laporan keuangan atau disebut juga kecurangan manajemen. Tindakan tersebut merupakan kelalaian dari manajemen untuk meningkatkan kinerja perusahaan, menutupi kerugian yang terjadi, dan memberikan keuntungan bagi manajemen. Manajemen dan Kantor Akuntan Publik (KAP) Tanubrata Sutanto Fahmi Bambang \& Rekan gagal dalam melakukan komunikasi mengenai kontrak dan aksi manajemen yang tidak menindaklanjutkan opini komite audit menyebabkan terjadinya kejahatan keuangan (Hari Prayoga et al., 2020).

Keberadaan seorang komite audit diperlukan untuk melakukan pengawasan internal perusahaan, meningkatkan efektivitas fungsi audit, memberikan kepastian terhadap kualitas laporan keuangan, menelaah risiko dan ketaatan terhadap Standar Akuntansi Keuangan (SAK) yang berlaku (Handoko \& Ramadhani, 2017). Manajemen risiko dan pelaksanaan audit guna menghindari kecurangan keuangan menjadi tanggung jawab seorang komite audit. Namun hal tersebut dapat menyebabkan ruang lingkup yang harus diperhatkan oleh komite audit semakin banyak maka komite audit lalai dalam melaksanakan kewajibannya. Maka itu, muncul pertimbangan untuk membentuk komite risiko yang berdiri sendiri yang terpisah dari komite audit (Abdullah \& Said, 2019).

Kejahatan keuangan dapat juga terjadi karena tata kelola perusahaan yang buruk, kurangnya pengawasan manajemen, penipuan, ketidakjujuran, atau karena kurangnya efektivitas kinerja manajemen perusahaan (Iswati et al., 2017). Tata kelola perusahaan yang baik dapat meminimalkan indikasi terjadinya kejahatan keuangan karena memiliki sifat mengatur dan mengontrol, dan menciptakan nilai tambahan bagi perusahaan dalam menyampaikan informasi yang akurat, tepat waktu, dan transparan kepada pemangku kepentingan (Nila Sari \& Husadha, 2020). Bila efektivitas komite dan tata kelola perusahaan bisa berjalan secara baik dapat menghindari terjadinya kejahatan keuangan korporasi. Berdasarkan uraian diatas, manajemen perusahaan mempengaruhi terjadi atau tidaknya kejahatan keuangan pada perusahaan BEI. Artikel ini menganalisis efektivitas komite dan mekanisme tata kelola perusahaan pada perusahaan yang terdaftar di BEI.

\section{Kejahatan Keuangan Korporasi}

\section{STUDI LITERATUR}

Kejahatan keuangan korporasi adalah berbagai jenis kejahatan dimana sebuah benda atau properi milik orang lain secara illegal digunakan untuk kepentingan pribadi. Keuntungan untuk kepentingan pribadi menjadi inti karakteristik dari kejahatan keuangan korporasi (Abdullah \& Said, 2018). Kejahatan keuangan memiliki dampak yang negatif bagi perusahaan dari berbagai aspek, mulai dari keuangan, reputasi, psikologi dan sosial. Kejahatan keuangan menyebabkan munculnya ketidakpercayaan pengguna informasi yang diungkapkan perusahaan (Dimitrijevic et al., 2020).

\section{Ukuran Komite Audit}

Efektivitas seorang komite audit dalam tanggung jawabnya untuk mengawasi pelaporan keuangan perusahaan dapat dilihat melalui kualitas laporan keuangan yang bebas dari kecurangan. Maka ukuran komite audit yang tepat dalam sebuah perusahaan akan mempengaruhi kualitas pelaporan keuangan yang dimonitor oleh komite audit (Kamolsakulchai, 2015). Komite audit juga memiliki tugas untuk mengawasi kinerja audit internal dan bekerja sama dengan audit eksternal perusahaan (Zager et al., 2016).

Kewajiban komite audit yang tidak sedikit juga harus diselesaikan tepat pada waktunya. Ukuran komite audit juga menyebabkan keahlian dan pengetahuan yang ada lebih banyak sehingga mampu memitigasi kejahatan keuangan korporasi. Maka semakin banyaknya anggota komite audit dianggap menyediakan keahlian dan pengetahuan yang lebih banyak dan luas, mampu menyelesaikan kewajibannya tepat waktu dan mampu mengawasi praktik kinerja dan meningkatkan kualitas pelaporan keuangan maka itu mengurangi kejahatan keuangan korporasi (Abdullah et al., 2019). Semakin banyak komite dengan latar belakang keuangan atau akuntansi yang ditunjuk menjadi komite audit, semakin sedikit kecurangan laporan keuangan yang akan terjadi (Ferdinand \& Santosa, 2019).

\section{$\mathrm{H}_{1}$ : Ukuran komite audit berpengaruh signifikan negatif terhadap kejahatan keuangan korporasi}

\section{Frekuensi Pertemuan Komite Audit}


Owner: Riset \& Jurnal Akuntansi

e-ISSN : 2548-9224 | p-ISSN : 2548-7507

Volume 6 Nomor 1, Januari 2022

DOI : https://doi.org/10.33395/owner.v6i1.546

Jumlah rapat komite berpengaruh terhadap efektivitas komite audit. Agar lebih efektif, anggota komite harus bersedia mencurahkan lebih banyak waktu mereka untuk audit (Kamolsakulchai, 2015). Komite audit yang melakukan rapat terus menerus menyebabkan pengawasan proses kinerja perusahaan yang lebih banyak dan ketat sehingga tidak memberikan peluang terjadinya kejahatan keuangan korporasi. Komite audit yang tidak berperan aktif menunjukan bahwa pengawasan manajemen perusahaan tidak berjalan secara efektif dan memungkinkan terjadi kejahatan keuangan (Nurliasari \& Achmad, 2020). Berdasarkan penelitian sebelumnya, frekuensi pertemuan komite audit yang efektif adalah sebanyak 4 (empat) kali dalam periode 1 tahun dimana persentase kehadiran dalam pertemuan paling sedikit 51\% (lima puluh satu persen) dari semua anggota (Dewi, 2019).

$\mathrm{H}_{2}$ : Frekuensi pertemuan komite audit berpengaruh signifikan negatif terhadap kejahatan keuangan korporasi

\section{Komite Risiko yang Berdiri Sendiri}

Secara tradisional, komite audit yang bertanggung jawab atas manajemen risiko. Maka tugas manajemen risiko perusahaan ditumpahkan kepada komite audit yang memiliki kewajiban lain yang harus dilakukan. Komite audit pun terbebani akan manajemen risiko perusahaan, membuat scope yang harus diperhatikan melebihi batas kemampuan seseorang (Abdullah et al., 2019). Fungsi manajemen risiko perusahaan mampu menyediakan kontrol perusahaan yang lebih baik, dan mampu memitigasi dan mencegah terjadinya kejahatan keuangan korporasi. Maka komite risiko yang terpisah dari komite audit yang terpisah lebih efektif daripada komite audit yang melaksanakan fungsi audit dan manajemen risiko secara bersamaan (Abdullah \& Said, 2019).

Adanya komite risiko yang berdiri sendiri dalam perusahaan tidak hanya mengurangi pengambilan risiko perusahaan namun juga dapat meningkatkan nilai perusahaan. Komite risiko yang berdiri sendiri dan terpisah dari komite audit juga mampu meningkatkan tata kelola perusahaan yang baik. Dengan berkurangnya pengambilan risiko oleh manajemen perusahaan, kejahatan keuangan pun berkurang (Bhuiyan et al., 2020). Variabel komite risiko yang berdiri sendiri menggunakan variabel dummy dimana perusahaan dikategorikan menjadi dua yaitu ada atau tidaknya komite risiko yang berdiri sendiri.

$\mathrm{H}_{3}$ : Komite risiko yang berdiri sendiri berpengaruh signifikan negatif terhadap kejahatan keuangan korporasi

\section{Kinerja Perusahaan}

Kinerja perusahaan dalam menghasilkan laba dapat mempengaruhi keputusan seorang investor. Kinerja perusahaan yang baik menyebabkan investor tertarik dengan perusahaan dan bersedia melakukan investasi dananya, begitu juga sebaliknya. Maka itu, kinerja perusahaan yang tidak baik menyebabkan perusahaan melakukan kejahatan keuangan (Arifin et al., 2016). Kinerja perusahaan yang tidak baik menyebabkan perusahaan merasa tertekan akibat kondisi keuangan yang tidak baik, dan kuatnya persaingan dengan kompetitor dalam dunia bisnis. Tekanan tersebut juga berasal dari tekanan eksternal seperti pemegang saham maupun kreditur. Hal tersebut memotivasi perusahaan untuk melakukan kejahatan keuangan dengan menutupi utang, menyajikan laporan keuangan yang salah (Nugroho et al., 2018).

\section{$\mathbf{H}_{4}$ : Kinerja perusahaan berpengaruh signifikan negatif terhadap kejahatan keuangan korporasi}

\section{Dewan Komisaris}

Pengawasan dilakukan sesuai dengan prinsip dasar kode etik dan prosedur yang ada sehingga dewan komisaris dapat menekan tingkat terjadinya kejahatan keuangan dalam perusahaan. Mekanisme pengawasan yang baik dapat menyebabkan direksi, manajer, maupun pihak lainnya takut untuk melakukan kejahatan keuangan (Vivianita \& Indudewi, 2019). Dewan komisaris bertanggung jawab akan ketepatan informasi yang disampaikan dalam laporan keuangan. Dewan komisaris mengawasi kinerja manajer dan memastikan terlaksananya tata kelola perusahaan yang baik sebagaimana sesuai dengan prosedur perusahaan yang berlaku (Priswita \& Taqwa, 2019). Namun adanya indikasi bahwa semakin banyaknya anggota dewan komisaris dapat meningkatkan kemungkinan terjadinya kejahatan 
Owner: Riset \& Jurnal Akuntansi

e-ISSN : 2548-9224 | p-ISSN : 2548-7507

Volume 6 Nomor 1, Januari 2022

DOI : https://doi.org/10.33395/owner.v6i1.546

keuangan, karena fungsi pengawasan yang tidak terpusat, dan sulit untuk melakukan koordinasi sehingga tidak efektif dalam mencegah fraud (Ismiyanti \& Prastichia, 2015).

\section{$\mathrm{H}_{5}$ : Dewan komisaris berpengaruh signifikan positif terhadap kejahatan keuangan korporasi}

\section{Kepemilikan Manajerial}

Kepemilikan manajerial dinilai dapat mengurangi permasalahan dalam sebuah perusahaan. Kepemilikan manajerial berarti bahwa manajer memiliki peran sebagai pemegang saham atau pemilik. Oleh karena itu pengelola (agen) akan bekerja sesuai dengan kepentingan pemegang saham (principal). Memiliki peran sebagai agen dan principal dalam waktu yang bersamaan, akan terjadi penurunan tingkat konflik kepentingan (Ferdinand \& Santosa, 2019). Kepemilikan saham manajerial baik untuk tata kelola perusahaan. Diasumsikan bahwa jika direktur memiliki kekayaan finansial pribadi yang cukup dipertaruhkan, direktur akan mulai berpikir lebih mirip dengan pemegang saham dan lebih mementingkan kinerja perusahaan (Abdullah et al., 2019).

\section{$\mathrm{H}_{6}$ : Kepemilikan manajerial berpengaruh signifikan negatif terhadap kejahatan keuangan korporasi}

\section{Kualitas Audit}

Kualitas audit adalah tingkat baik atau tidaknya seorang auditor dalam menemukan dan melaporkan pelanggaran yang terjadi yang melanggar sistem akuntansi kliennya. Baiknya kualitas audit menunjukan efektivitas pencegahan dan mengurangi peluang untuk melakukan laporan keuangan yang mengandung kecurangan. Kualitas audit yang baik yang menemukan dan mengungkapkan penipuan yang terjadi mampu merusak reputasi manajemen perusahaan dan berdampak menurunnya nilai di mata pemangku kepentingan, investor, maupun publik. Semakin baik layanan audit yang diberikan, maka kecurangan yang terdeteksi juga semakin tinggi (Utomo et al., 2019). Seorang auditor yang memiliki pendidikan, kemampuan, keahlian, dan kompetensi yang lebih baik akan menghasilkan kualitas atau layanan audit yang baik dan transparan bagi kliennya, maka semakin besar KAP audit yang melaksanakan audit maka semakin banyak kesalahan maupun salah saji yang diungkapkan dalam pelaporan (Vivianita \& Indudewi, 2019). Auditor eksternal yang bereputasi baik akan menyediakan kualitas audit yang baik juga. Maka Big Four memiliki kualitas audit yang lebih baik daripada KAP Non-Big Four (Riyanti et al., 2019). Variabel kualitas audit menggunakan variabel dummy dimana perusahaan dikategorikan menjadi dua yaitu Big Four dan Non-Big Four.

\section{$\mathrm{H}_{7}$ : Kualitas audit berpengaruh signifikan negatif terhadap kejahatan keuangan korporasi}

\section{Data dan Sampel Penelitian}

\section{METODE}

Metode yang digunakan dalam penelitian ini adalah metode penelitian kuantitatif korelasional dimana data yang digunakan merupakan data angka atau numerial yang akan diolah secara statistika. Pengumpulan data sampel menggunakan objek penelitian berupa perusahaan terbuka yang terdaftar dalam Bursa Efek Indonesia (BEI) pada periode 2016-2020. Sampel penelitian dipilih dengan menggunakan metode Purposive Sampling dimana dipilih dari teknik pengambil sampel non-randomi untuk mendapatkan hasil penelitian yang lebih tepat dan menemukan solusi atau jawaban atas hipotesis yang telah disusun. Pemilihan sampel penelitian didasarkan oleh sebuah kriteria dimana perusahaan terbuka BEI memiliki laporan tahunan yang lengkap mulai dari periode 2016-2020, dan objek-objek penelitian yang diteliti harus telah diungkapkan pada laporan tersebut untuk mencegah adanya distorsi pada proses pengujian data sampel. Sampel dan data dari penelitian adalah sebagai berikut:

Tabel 1. Pemilihan sampel dan Data Penelitian

\begin{tabular}{|l|rl|}
\hline \multicolumn{1}{|c|}{ Kriteria } & \multicolumn{2}{c|}{ Jumlah } \\
\hline Perusahaan yang terdaftar di BEI sampai periode 2016 & 513 & perusahaan \\
\hline Perusahaan yang tidak menyajikan informasi secara lengkap & $(87)$ & perusahaan \\
\hline Total perusahaan yang menjadi sampel & 426 & perusahaan \\
\hline Jumlah data penelitian & 2.130 & data \\
\hline
\end{tabular}


Owner: Riset \& Jurnal Akuntansi

e-ISSN : 2548-9224 | p-ISSN : 2548-7507

Volume 6 Nomor 1, Januari 2022

DOI : https://doi.org/10.33395/owner.v6i1.546

\begin{tabular}{|l|l|}
\hline Jumlah data outlier & $(226)$ data \\
\hline Jumlah data penelitian & 1.904 data \\
\hline
\end{tabular}

Sumber tabel: Data sekunder diolah (2021)

\section{Pengukuran Variabel}

Tabel 2. Pengukuran Variabel

\begin{tabular}{|c|c|c|}
\hline No & Variabel & Pengukuran \\
\hline 1 & $\begin{array}{l}\text { Kejahatan Keuangan } \\
\text { Korporasi (Y) }\end{array}$ & $\begin{array}{l}\text { Kode: } \\
1=\text { adanya insidensi kejahatan keuangan pada periode } t \\
0 \\
=\text { tidak adanya insidensi kejahatan keuangan pada periode } t\end{array}$ \\
\hline 2 & $\begin{array}{l}\text { Ukuran Komite Audit } \\
\left(\mathrm{X}_{1}\right)\end{array}$ & Komite Audit $=\Sigma$ Komite Audit periode $t$ \\
\hline 3 & $\begin{array}{l}\text { Frekuensi Pertemuan } \\
\text { Komite Audit }\left(\mathrm{X}_{2}\right)\end{array}$ & Frekuensi Pertemuan $=\Sigma$ Pertemuan komite audit periode $t$ \\
\hline 4 & $\begin{array}{l}\text { Komite Risiko yang } \\
\text { Berdiri Sendiri }\left(\mathrm{X}_{3}\right)\end{array}$ & $\begin{array}{l}\text { Kode: } \\
1=\text { memiliki komite risiko yang berdiri sendiri } \\
0=\text { tidak memiliki komite risiko yang berdiri sendiri }\end{array}$ \\
\hline 5 & $\begin{array}{l}\text { Kinerja Perushaaan } \\
\left(\mathrm{X}_{4}\right)\end{array}$ & $\begin{array}{l}\text { Kinerja Perusahaan }=R O A \\
\qquad=\frac{\text { Laba }(\text { rugi }) \text { tahun berjalan periode } t}{\text { Total asset periode } t}\end{array}$ \\
\hline 6 & $\begin{array}{l}\text { Dewan Komisaris } \\
\left(\mathrm{X}_{5}\right)\end{array}$ & Dewan komisaris $=\Sigma$ Dewan komisaris periode $t$ \\
\hline 7 & $\begin{array}{l}\text { Kepemilikan } \\
\text { Manajerial }\left(\mathrm{X}_{6}\right)\end{array}$ & $\begin{array}{l}\text { Kepemilikan Manajerial } \\
\qquad=\frac{\text { Kepemilikan saham manajemen periode } t}{\text { Total saham beredar periode } t}\end{array}$ \\
\hline 8 & Kualitas Audit $\left(\mathrm{X}_{7}\right)$ & $\begin{array}{l}\text { Kode: } \\
1=\text { audit eksternal berupa Big Four pada periode } t \\
0=\text { audit eksternal berupa Non - Big Four pada periode } t\end{array}$ \\
\hline
\end{tabular}

\section{Metode Analisis Data}

Metode analisis data penelitian ini adalah metode analisis regresi logistik, dimana menganalis hubungan antar variabel dependen yang bersifat dummy dengan variabel independens. Program untuk melakukan pengujian data guna untuk menganalisis data yang dipilih adalah program statistika berupa SPSS. Langkah-langkah analisis data dimulai dari uji outlier, uji statistik deskriptif, uji multikolinearitas, uji hipotesis dimulai dari uji koefisien determinasi dan uji kelayakan model regresi, kemudian dilakukan uji $t /$ wald menggunakan program statistika SPSS.

\section{Uji Statistika Deskriptif}

\section{HASIL}

Statistik deskriptif adalah metode analisis data yang memberikan gambaran atau mendeskripsikan data dimana data variabel yang diolah adalah nilai minimum, maksimum, jumlah sampel, nilai rata-rata, jumlah total variabel, dan standar deviasi. Metode ini digunakan untuk melihat perbedaan antar data sampel yang telah dikumpulkan.

Tabel 3. Hasil Uji Statistik Deskriptif Variabel Penelitian

\begin{tabular}{|l|c|c|c|c|c|}
\hline \multicolumn{1}{|c|}{ Variabel } & N & Min & Max & Mean & $\begin{array}{c}\text { Std. } \\
\text { Deviation }\end{array}$ \\
\hline Jumlah Anggota Komite Audit & 1904 & 2 & 7 & 3.06 & 0.346 \\
\hline Jumlah Pertemuan Komite Audit & 1904 & 0 & 27 & 6.47 & 4.021 \\
\hline Kinerja Perusahaan (ROA) & 1904 & $-68.24 \%$ & $71.60 \%$ & $1.83 \%$ & $10.23 \%$ \\
\hline
\end{tabular}


Owner: Riset \& Jurnal Akuntansi

e-ISSN : 2548-9224 | p-ISSN : 2548-7507

Volume 6 Nomor 1, Januari 2022

DOI : https://doi.org/10.33395/owner.v6i1.546

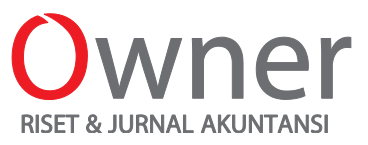

\begin{tabular}{|l|c|c|c|c|c|}
\hline Dewan Komisaris & 1904 & 1 & 9 & 4.14 & 1.655 \\
\hline Kepemilikan Manajerial & 1904 & $0.00 \%$ & $41.35 \%$ & $2.73 \%$ & $7.11 \%$ \\
\hline Valid N (listwise) & 1904 & & & & \\
\hline
\end{tabular}

Sumber tabel: Data sekunder diolah SPSS 25 (2021)

Dari hasil uji yang ditampilkan pada Tabel 3, dapat diketahui bahwa variabel ukuran komite audit memiliki nilai minimum sebesar 2 orang, dan nilai maksimum komite audit adalah 7 orang dimana nilai rata-ratanya sebesar 3.06 orang. Hasil penelitian ini menunjukan bahwa majoritas sampel penelitian telah memenuhi Peraturan Otoritas Jasa Keuangan (POJK) NOMOR /POJK.04/2016 pasal 28 (2) tentang banyaknya anggota komite audit dalam sebuah perusahaan dimana minimal 3 (tiga) orang yang berasal dari Komisaris Independen dan/atau pihak dari luar Perusahaan Efek. Hasil penelitian menunjukan banyaknya perusahaan yang terdaftar di BEI yang belum memenuhi syarat POJK pasal 28 (2) dimana jumlah komite audit pada perusahaan hanya ada 2 orang.

Variabel frekuensi pertemuan komite audit menunjukan nilai minimum 0 dan nilai maksimun adalah 27 dengan nilai rata-rata 6.47 kali. Pada POJK NOMOR /POJK.04/2016 pasal 31 (1) dikatakan rapat komite audit diselenggarakan sesuai dengan kebutuhan Perusahaan Efek. Maka itu tidak adanya peraturan mengenai jumlah pertemuan komite audit yang harus terjadi dalam periode 1 tahun. Namun dapat dilihat dari nilai minimum variabel bahwa PT AirAsia Indonesia Tbk belum melakukan pertemuan antar komite audit dalam kurun waktu 1 tahun pada tahun 2017.

Variabel kinerja perusahaan yang diukur menggunakan ROA mempunyai nilai minimum $68.24 \%$ dan nilai maksimum $71.60 \%$. Kinerja perusahaan yang paling rendah sebesar $-68,24 \%$ dimiliki oleh PT Intan Baruprana Finance Tbk tahun 2020 yang artinya kemampuan perseroan dalam memanfaatkan asset untuk menghasilkan laba masih rendah. Sebaliknya, kinerja perusahaan yang paling tinggi sebesar 71.60\% dimiliki oleh Multi Prima Sejahtera Tbk pada periode 2017 artinya perseroan mampu memanfaatkan assetnya untuk menghasilkan laba yang tinggi.

Variabel dewan komisaris memiliki nilai minimum sebanyak 1 orang, sedangkan nilai maksimunnya sebanyak 9 orang. Nilai rata-rata dari variabel adalah 4,14 orang. Pada POJK NOMOR /POJK.04/2016 pasal 18 (2) menyebutkan bahwa ukuran dewan komisaris tidak melebihi jumlah anggota direksi. Dapat diketahui bahwa PT Bank Negara Indonesia Tbk memiliki anggota dewan komisaris sebanyak 9 orang sedangkan anggota direksi perusahaan sebanyak 12 orang dengan arti PT Astra International Tbk tidak memenuhi POJK yang berlaku.

Variabel kepemilikan manajerial diukur dengan menghitung persentase kepemilikan manajemen dengan rumus saham yang dimiliki manajemen / saham yang beredar. Dapat dilihat dari tabel bahwa nilai minimum kepemilikan manajerial perusahaan adalah 0 dan nilai maksimum manajerial perusahaan adalah $41.35 \%$ dengan nilai rata-rata $2.731 \%$. Perusahaan dengan nilai kepemilikan manajerial terbesar adalah PT Elang Mahkota Teknologi Tbk dengan arti perseroan memberikan hak memegang saham dalam jumlah yang signifikan kepada pemangku kepentingan. Namun dilihat dari rata-rata kepemilikan manajerial, angkanya mendekati nilai minimum menandakan banyak perusahaan yang tidak memberikan hak terhadap pemangku kepentingan untuk memegang saham perusahaan.

Adanya variabel dummy yang digunakan dalam penelitian yaitu kejahatan keuangan korporasi, komite risiko yang berdiri sendiri dan kualitas audit, maka itu memiliki tabel statistik deskriptif yang terpisah.

Tabel 4. Hasil Uji Statistik Deskriptif Variabel Dummy Kejahatan Keuangan Korporasi

\begin{tabular}{|l|r|r|}
\hline \multicolumn{1}{|c|}{ Kategori } & Frekuensi & \multicolumn{1}{c|}{ Persentase } \\
\hline 0 = Tidak ada Insidensi Kejahatan Keuangan & 1.836 & $96.4 \%$ \\
\hline 1= Ada Insidensi Kejahatan Keuangan & 68 & $3.6 \%$ \\
\hline Total & 1.904 & $100.0 \%$ \\
\hline
\end{tabular}

Sumber tabel: Data sekunder diolah SPSS 25 (2021)

Dari hasil uji yang ditampilkan pada Tabel 4, dapat diketahui bahwa dari 100\% perusahaan yang telah diuji, hanya terdapat $3.6 \%$ perusahaan yang memiliki insidensi kejahatan keuangan korporasi, 
Owner: Riset \& Jurnal Akuntansi

e-ISSN : 2548-9224 | p-ISSN : 2548-7507

Volume 6 Nomor 1, Januari 2022

DOI : https://doi.org/10.33395/owner.v6i1.546

sedangkan sisanya tidak memiliki insidensi kejahatan keuangan yang terjadi. Maka dapat disimpulkan bahwa mayoritas perusahaan yang terdaftar dalam BEI tidak memiliki insidensi kejahatan keuangan korporasi.

Tabel 5. Hasil Uji Statistik Deskriptif Variabel Dummy Komite Risiko yang Berdiri Sendiri

\begin{tabular}{|l|r|r|}
\hline \multicolumn{1}{|c|}{ Kategori } & Frekuensi & \multicolumn{1}{|c|}{ Persentase } \\
\hline 0 = Tidak ada Komite Risiko yang Berdiri Sendiri & 1.641 & $86.2 \%$ \\
\hline 1= Ada Komite Risiko yang Berdiri Sendiri & 263 & $13.8 \%$ \\
\hline Total & 1.904 & $100.0 \%$ \\
\hline
\end{tabular}

Sumber tabel: Data sekunder diolah SPSS 25 (2021)

Dari hasil uji yang ditampilkan pada Tabel 5, dapat diketahui bahwa lebih dari 13.8\% perusahaan yang menjadi sampel penelitian memiliki komite risiko yang berdiri sendiri dan terpisah dari tanggung jawab manajemen perusahaan, maka dapat disimpulkan bahwa mayoritas perusahaan yang terdaftar dalam BEI tidak memiliki komite manajemen risiko yang berdiri sendiri.

Tabel 6. Hasil Uji Statistik Deskriptif Variabel Dummy Kualitas Audit

\begin{tabular}{|l|r|r|}
\hline \multicolumn{1}{|c|}{ Kategori } & Frekuensi & \multicolumn{1}{c|}{ Persentase } \\
\hline $0=$ Non-Big Four & 1.188 & $61.8 \%$ \\
\hline $1=$ Big Four & 730 & $38.2 \%$ \\
\hline Total & 1.918 & $100.0 \%$ \\
\hline
\end{tabular}

Sumber tabel: Data sekunder diolah SPSS 25 (2021)

Dari hasil uji yang ditampilkan pada Tabel 6, dapat diketahui bahwa perusahaan sampel penelitian yang menggunakan jasa audit Non-Big Four sebanyak 61.8\%. Sedangkan 38.2\% lainnya menggunakan jasa audit Big Four. Maka dapat disimpulkan bahwa mayoritas perusahaan yang terdaftar di BEI menggunakan jasa audit Non-Big Four.

\section{Uji Multikolinearitas}

Model penelitian dikatakan baik atau layak bila hasil pengujian tidak menunjukan adanya korelasi antar variabel independen model regresinya. Uji multikolineraritas dapat dilihat melalui nilai Variance Inflation Factor (VIF) dimana bila nilai VIF < 10 maka tidak terdapat multikolinearitas. Bila nilai VIF $>10$, maka terdapat multikolinearitas antar variabel independen yang digunakan. Dari hasil uji yang ditampilkan pada Tabel 7, dapat diketahui bahwa antar variabel independen dari model regresi yang dipilih, tidak terjadi multikolinearitas dengan arti tidak adanya korelasi antar variabel independen yang dipilih, dan model regresi yang dipilih dapat dikatakan baik.

Tabel 7. Hasil Uji Multikolinearitas

\begin{tabular}{|l|r|r|r|}
\hline & \multicolumn{2}{|c|}{ Collinearity Statistics } & \multirow{2}{*}{ Kesimpulan } \\
\hline & Tolerance & \multicolumn{1}{|c|}{ VIF } & \multirow{2}{*}{ Tidak ada multikolinearitas } \\
\hline Ukuran Komite Audit & 0.894 & 1.118 & Tidan \\
Frekuensi Rapat Komite Audit & 0.832 & 1.202 & Tidak ada multikolinearitas \\
\hline Keberadaan Komite Risiko & 0.822 & 1.216 & Tidak ada multikolinearitas \\
\hline Kinerja Perusahaan & 0.962 & 1.039 & Tidak ada multikolinearitas \\
\hline Dewan Komisaris & 0.889 & 1.124 & Tidak ada multikolinearitas \\
\hline Kepemilikan Manajerial & 0.994 & 1.006 & Tidak ada multikolinearitas \\
\hline Kualitas Audit & 0.886 & 1.129 & Tidak ada multikolinearitas \\
\hline
\end{tabular}

Sumber tabel: Data sekunder diolah SPSS 25 (2021)

\section{Uji Koefisien Determinasi (Nagelkerke R Square)}

Nilai di antara 0 dan 1 menjadi penentu dalam pengujian koefisien determinasi (R2) dimana bila nilai R2 mencondong ke nilai 1 menunjukan bahwa kemampuan variabel bebas dalam menjelaskan 
Owner: Riset \& Jurnal Akuntansi

e-ISSN : 2548-9224 | p-ISSN : 2548-7507

Volume 6 Nomor 1, Januari 2022

DOI : https://doi.org/10.33395/owner.v6i1.546

variabel dependen tersebut besar. Sebaliknya bila nilai R2 lebih mencondong ke nilai 0 maka kemampuan variabel bebas dalam menjelaskan variabel dependen kecil. Dari hasil uji yang ditampilkan pada Tabel 8, dapat dikatakan bahwa variabel independen dari model penelitian yang dipilih dapat menjelaskan variabel dependen berupa kejahatan keuangan korporasi sebesar $42.4 \%$. Sedangkan 57.6\% lainnya dapat dijelaskan oleh variabel independen lainnya yang tidak digunakan dalam penelitian.

Tabel 8. Hasil Uji Koefisien Determinasi

\begin{tabular}{|c|c|}
\hline Variabel & Nagelkerke R Square \\
\hline Kejahatan Keuangan Korporasi & 0.424 \\
\hline
\end{tabular}

Sumber tabel: Data sekunder diolah SPSS 25 (2021)

\section{Uji Kelayakan Model Regresi (Hosmer dan Lemeshow's Goodness of Fit)}

Model penelitian dikatakan layak bila nilai F (Sig.) lebih besar dari 0,05. Metode penelitian yang layak berarti model regresi yang digunakan mampu menjelaskan pengaruh variabel independen terhadap variabel dependen dengan arti mampu menjelaskan hipotesis yang telah dikembangkan. Dari hasil uji yang ditampilkan pada Tabel 9, menunjukan nilai signifikansi sebesar 0,557 dimana $>0.05$, dengan arti model penelitian yang dipilih sudah sesuai dan layak digunakan.

Tabel 9. Hasil Uji Kelayakan Model Regresi

\begin{tabular}{|c|c|c|}
\hline Chi-square & Sig. & Kesimpulan \\
\hline 6.628 & 0.577 & Model penelitian sesuai dan dapat digunakan \\
\hline \multicolumn{3}{|c|}{ Sumber tabel: Data sekunder diolah SPSS 25 (2021) }
\end{tabular}

\section{Uji Regresi Logistik}

Uji regresi logistik disebut juga sebagai uji $t /$ wald dimana digunakan untuk menganalisis apakah hipotesis yang telah dikembangkan terbukti atau tidak. Hipotesis dikatakan terbukti dan memiliki pengaruh yang signifikan bila nilai sig. $<0.05$, namun hipotesis dianggap tidak memiliki pengaruh yang signifikan bila nilai sig. $>0.05$.

Tabel 10. Hasil Uji Regresi Logistik

\begin{tabular}{|l|c|c|}
\hline & B & Sig. \\
\hline Ukuran Komite Audit & 1.570 & 0.000 \\
\hline Frekuensi Pertemuan Komite Audit & -0.039 & 0.203 \\
\hline $\begin{array}{l}\text { Keberadaan Komite Risiko yang } \\
\text { Berdiri Sendiri }\end{array}$ & -2.375 & 0.000 \\
\hline Kinerja Perusahaan & -0.031 & 0.046 \\
\hline Dewan Komisaris & 0.020 & 0.824 \\
\hline Kepemilikan Manajerial & -1.364 & 0.078 \\
\hline Kualitas Audit & -2.224 & 0.000 \\
\hline Constant & -5.490 & 0.000 \\
\hline
\end{tabular}

Sumber tabel: Data sekunder diolah SPSS 25 (2021)

\section{PEMBAHASAN}

$\mathrm{H}_{1}$ : Ukuran komite audit berpengaruh signifikan negatif terhadap kejahatan keuangan korporasi

Dari hasil uji yang ditampilkan pada tabel 10, hasil uji menunjukan hasil signifikansi 0.000 dimana menunjukan adanya pengaruh signifikan antara ukuran komite audit terhadap kejahatan keuangan korporasi. Nilai B yang dihasilkan sebesar 1.570 menunjukan pengaruh yang signifikan positif antara komite audit terhadap kejahatan keuangan korporasi. Maka dapat disimpulkan bahwa $\mathrm{h}_{1}$ dimana ukuran komite audit berpengaruh signifikan negatif terhadap insidensi kejahatan keuangan tidak terbukti. Hasil penelitian menunjukan bahwa anggota komite audit yang semakin banyak, maka semakin tinggi kemungkinan terjadinya kejahatan keuangan korporasi dalam sebuah perusahaan, 
Hasil penelitian konsisten dengan peneliti sebelumnya yang menyatakan bahwa ukuran komite audit memiliki pengaruh yang signifikan positif terhadap kejahatan keuangan korporasi (Tiapandewi et al., 2020). Hasil penelitian menunjukan bahwa semakin besarnya jumlah anggota komite audit dalam perusahaan dapat menimbulkan konflik antar anggota akibat banyaknya perbedaan pendapat sehingga menghambat komite audit dalam pengambilan keputusan (Siswanto \& Soedharto, 2017). Tanggung jawab komite audit dalam pengawasan manajemen perusahaan dan melakukan audit guna menghasilkan laporan keuangan yang berkualitas dan bebas dari kecurangan pun terhambat. Pengawasan yang tidak maksimal dapat meningkatkan terjadi kejahatan keuangan dalam korporasi.

Namun tidak konsisten dengan hasil penelitian peneliti lainnya dimana ukuran komite audit tidak memiliki pengaruh signifikan terhadap kejahatan keuangan korporasi (W. N. Abdullah \& Said, 2019; Aghghaleh et al., 2014; Nurliasari \& Achmad, 2020).

\section{$\mathrm{H}_{2}$ : Frekuensi pertemuan komite audit berpengaruh signifikan negatif terhadap kejahatan keuangan korporasi}

Hasil regresi logistik yang dilakukan dalam penelitian menunjukan signifikansi 0.203 dengan nilai B sebesar -0.039 menunjukan tidak adanya pengaruh yang signifikan secara negatif antara frekuensi pertemukan komite audit terhadap kejahatan keuangan korporasi. Maka dapat disimpulkan bahwa $\mathrm{h}_{2}$ dimana frekuensi pertemuan komite audit berpengaruh signifikan negatif terhadap kejahatan keuangan korporasi tidak terbukti.

Hasil penelitian konsisten dengan hasil penelitian yang dilakukan sebelumnya dimana frekuensi pertemuan komite audit tidak memiliki pengaruh yang signifikan terhadap kejahatan keuangan korporasi (Abdullah et al., 2019; Abdullah \& Said, 2019; Dewi, 2019; Prasetyo, 2014; Ruchiatna et al., 2020). Ruchiatna et al., (2020) menyatakan bahwa semakin banyak atau tidaknya rapat komite audit dalam periode 1 tahun tidak memiliki pengaruh yang signifikan karena hasil rapat tidak ditindaklanjutkan baik oleh pihak manajemen maupun pihak eksternal. Maka rapat yang dilakukan tidak efektif dalam mengurangi terjadinya kejahatan keuangan dalam perusahaan.

\section{$\mathrm{H}_{3}$ : Komite risiko yang berdiri sendiri berpengaruh signifikan negatif terhadap kejahatan keuangan korporasi}

Hasil penelitian menunjukan nilai signifikansi sebesar 0.000 menyatakan bahwa komite risiko yang berdiri sendiri memiliki pengaruh yang signifikan terhadap kejahatan keuangan korporasi. Nilai B yang dihasilkan sebesar -2.375 menunjukan pengaruh yang signifikan negatif. Maka dapat disimpulkan bahwa $h_{3}$ dimana komite risiko yang berdiri sendiri berpengaruh signifikan negatif terhadap kejahatan keuangan korporasi terbukti.

Hasil penelitian konsisten dengan penelitian yang telah dilakukan oleh oleh W. N. Abdullah \& Said (2019) dan W. N. Abdullah et al., (2019). Penelitian (Abdullah \& Said, 2019) menyatakan bahwa seorang komite risiko yang berdiri sendiri dapat mengurangi terjadinya kejahatan keuangan korporasi dikarenakan adanya manajemen risiko yang lebih efektif dan meningkatkan nilai perusahaan. Manajemen perusahaan yang merangkap tanggung jawab seperti komite audit yang merangkap dalam pengawasan audit dan manajemen risiko menyebabkan komite audit merasa terbebani dan tidak mampu menjalankan semua kewajiban secara maksimal.

\section{$\mathrm{H}_{4}$ : Kinerja perusahaan berpengaruh signifikan negatif terhadap kejahatan keuangan korporasi}

Hasil regresi logistik dalam penelitian menujukan nilai signifikansi sebesar 0.046 menyatakan bahwa kinerja perusahaan memiliki pengaruh yang signifikan terhadap insidensi kejahatan keuangan. Nilai B yang dihasilkan sebesar -0.031 menunjukan pengaruh yang signifikan negatif. Maka dapat disimpulkan bahwa $\mathrm{h}_{4}$ dimana kinerja perusahaan berpengaruh signifikan negatif terhadap kejahatan keuangan korporasi terbukti.

Hasil penelitian menunjukan hasil yang sama dengan penelitian yang dilakukan oleh beberapa peneliti (Arifin et al., 2016; Hanifa \& Laksito, 2015; Nugroho et al., 2018) dimana kinerja perusahaan berpengaruh signifikan negatif terhadap kejahatan keuangan korporasi. Hanifa \& Laksito (2015) menyatakan bahwa kinerja perusahaan yang dimana dilihat berdasarkan Return on Asset (ROA) perusahaan yang semakin tinggi, dengan arti perusahaan menghasilkan laba tahun berjalan yang tinggi 
Owner: Riset \& Jurnal Akuntansi

e-ISSN : 2548-9224 | p-ISSN : 2548-7507

Volume 6 Nomor 1, Januari 2022

DOI : https://doi.org/10.33395/owner.v6i1.546

dari aset perusahaan maka tidak menimbulkan keinginan bagi perusahaan untuk melakukan kejahatan keuangan korporasi seperti kecurangan laporan keuangan untuk memperindah laporan keuangan perusahaan. Sebaliknya, bila ROA perusahaan rendah, maka kemungkinan terjadinya kecurangan laporan keuangan meningkat untuk meningkatkan laba dan menarik perhatian investor untuk melakukan investasi.

Namun hasil penelitian tersebut tidak konsisten dengan penelitian yang dilakukan oleh Hidayatun \& Juliarto (2019), Vivianita \& Indudewi (2019) dan Martantya \& Daljono (2013) dimana menyatakan bahwa kinerja perusahaan memiliki pengaruh signifikan positif terhadap kejahatan keuangan korporasi.

\section{$\mathrm{H}_{5}$ : Dewan komisaris berpengaruh signifikan positif terhadap kejahatan keuangan korporasi}

Hasil regresi logistik dalam penelitian menunjukan nilai signifikansi sebesar 0.824 dan nila B sebesar 0.020 menyatakan bahwa dewan komisaris memiliki pengaruh yang tidak signifikan positif terhadap insidensi kejahatan keuangan. Maka dapat disimpulkan bahwa $\mathrm{h}_{5}$ dimana dewan komisaris berpengaruh signifikan positif terhadap kejahatan keuangan korporasi tidak terbukti.

Hasil penelitian konsisten dengan penelitian yang dilakukan oleh Dewi (2019), Mardianto \& Tiono (2019), dan Wicaksono \& Chariri (2015). Mardianto \& Tiono (2019) menyatakan bahwa dewan komisaris memiliki tanggung jawab utama untuk mewujudkan tata kelola perusahaan yang baik maka mengurangi terjadinya kejahatan keungan korporasi perusahaan bukan merupakan tanggung jawab utama seorang dewan komisaris. Dewan komisaris kurang efektif dan optimal dalam menjalankan tanggung jawabnya sehingga tidak memiliki pengaruh yang signifikan terhadap penekanan terjadinya kejahatan keuangan dalam korporasi (Dewi, 2019; Vivianita \& Indudewi, 2019). Namun hasil penelitian tidak konsisten dengan penelitian yang dilakukan oleh Ismiyanti \& Prastichia (2015) dimana dewan komisaris berpengaruh signifikan positif terhadap insidensi kejahatan keuangan.

\section{$H_{6}$ : Kepemilikan manajerial berpengaruh signifikan negatif terhadap kejahatan keuangan korporasi}

Hasil regresi logistik dalam penelitian menunjukan hasil signifikansi sebesar 0.078 dan B sebesar 1.364 menyatakan bahwa kepemilikan manajerial memiliki pengaruh yang tidak signifikan negatif terhadap insidensi kejahatan keuangan. Maka dapat disimpulkan bahwa $\mathrm{h}_{6}$ dimana kepemilikan manajerial berpengaruh signifikan negatif terhadap kejahatan keuangan korporasi tidak terbukti.

Hasil penelitian menunjukan hasil yang sama dengan penelitian yang dilakukan oleh Dewi (2019) Priswita \& Taqwa (2019) namun tidak selaras dengan penelitian yang dilakukan peneliti sebelumnya dimana kepemilikan manajerial berpengaruh signifikan negatif terhadap kepemilikan manajerial (Ferdinand \& Santosa, 2019; Ismiyanti \& Prastichia, 2015; Utomo et al., 2019). Dewi (2019), Priswita \& Taqwa (2019) menyatakan bahwa sebagian besar pihak manajemen tidak memiliki saham yang besar dalam perusahaan sehingga kurangnya rasa loyalitas maupun keinginan manajemen dalam memaksimalkan tanggung jawab dalam kinerjanya. Dapat dilihat melalui hasil penelitian dimana ratarata kepemilikan manajerial perusahaan hanya sebesar $2.73 \%$ mendekati $0 \%$ sehingga manajemen tidak dapat merasakan keuntungan yang maksimal melalui saham yang dimiliki didalam perusahaan sehingga kepentingan perusahaan tidak menjadi prioritas manajemen maka kepemilikan manajerial tidak berpengaruh signifikan terhadap terjadi atau tidaknya kejahatan keuangan dalam korporasi (Priswita \& Taqwa 2019).

\section{$\mathrm{H}_{7}$ : Kualitas audit berpengaruh signifikan negatif terhadap kejahatan keuangan korporasi}

Hasil penelitian menunjukan nilai signifikansi sebesar 0.000 menyatakan bahwa kualitas audit memiliki pengaruh yang signifikan terhadap kejahatan keuangan korporasi. Nilai B yang dihasilkan sebesar -2.224 menunjukan adanya pengaruh yang signifikan negatif. Maka dapat disimpulkan bahwa $\mathrm{h}_{7}$ dimana kualitas audit memiliki pengaruh yang signifikan negatif terhadap kejahatan keuangan korporasi terbukti.

Hasil penelitian menunjukan hasil yang konsisten dengan penelitian yang dilakukan oleh (Utomo et al., 2019). Peneliti menyatakan bahwa Big Four memiliki kemampuan dan pengalaman yang lebih baik dalam audit sehingga menghasilkan audit yang berkualitas. Big Four melakukan secara objektif sehingga mampu mendeteksi kecurangan dalam laporan keuangan perusahaan. Dengan begitu, 
manajemen dapat merasa tertekan dalam melakukan kecurangan dan mampu mengurangi terjadinya kejahatan keuangan dalam korporasi. Namun hasil penelitian tidak konsisten dengan penelitian yang dilakukan beberapa peneliti dimana kualitas audit tidak memiliki pengaruh yang signifikan terhadap kejahatan keuangan korporasi (Hanifa \& Laksito, 2015; Riyanti et al., 2019; Vivianita \& Indudewi, 2019).

\section{KESIMPULAN}

Dari hasil penelitian menunjukan bahwa keberadaan komite risiko yang berdiri sendiri, kinerja perusahaan, dan kualitas audit memiliki pengaruh yang signifikan negatif terhadap kejahatan keuangan korporasi dimana membuktikan hipotesis penelitian. Komite risiko yang berdiri sendiri lebih efektif dalam dibandingkan dengan komite audit yang merangkap sebagai komite risiko dalam struktur organisasi perusahaan karena menghindari adanya kelalaian manajemen akibat luasnya ruang lingkup pengawasan manajemen sehingga manajemen risiko dapat dilakukan secara maksimal oleh komite risiko yang berdiri sendiri dan menekan terjadinya kejahatan keuangan korporasi.

Kinerja perusahaan yang semakin baik mampu menekan manajemen untuk tidak melakukan kecurangan laporan keuangan guna memanipulasi informasi yang diterima publik. Sedangkan kualitas audit dimana KAP selaku auditor laporan keuangan perusahaan yang semakin besar (Big Four) menandakan semakin baiknya kualitas audit yang diberikan sehingga mampu mendeteksi kecurangan laporan keuangan perusahaan. Hal tersebut dapat mengurangi keinginan dilakukannya kejahatan keungan korporasi dalam perusahaan.

Hasil penelitian menunjukan bahwa ukuran komite audit berpengaruh signifikan positif dimana tidak membuktikan hipotesis penelitian. Ukuran komite audit yang semakin banyak dapat menimbulkan konflik antar anggota dan menyebabkan sulitnya pengambilan keputusan dalam melaksanakan kewajibannya untuk mengawasi dan mengaudit sehingga meningkatkan terjadinya kejahatan keuangan korporasi akibat tidak efektifnya komite audit dalam melaksanakan tanggung jawabnya.

Namun hasil penelitian menunjukan bahwa jumlah rapat komite audit, dewan komisaris, dan kepemilikan manajerial tidak memiliki pengaruh yang signifikan terhadap terjadinya kejahatan keuangan korporasi. Semakin banyaknya rapat yang dilakukan oleh komite audit dalam kurun waktu satu tahun membuktikan semakin banyaknya hasil rapat yang dihasilkan. Namun hasil rapat diperlukan tindaklanjut dari manajemen maupun pihak eksternal untuk menekan terjadinya kejahatan keuangan.

Anggota dewan komisaris yang menaungi komite audit perlu untuk melakukan tindaklanjut dari hasil rapat komite audit. Namun seorang dewan komisaris memiliki tugas utama untuk membentuk tata kelola perusahaan yang baik sehingga penekanan terjadinya kejahatan keuangan menjadi tidak optimal maka tidak memiliki pengaruh yang signifikan antara anggota dewan komisaris dan kejahatan keuangan korporasi.

Kepemilikan manajerial yang dimiliki sebagian besar perusahaan tidak banyak dapat dilihat dari hasil penelitian terhadap kepemilikan manajerial sebesar $2.73 \%$ mendekati $0 \%$. Kepemilikan manajerial yang kecil tidak menghasilkan keuntungan yang besar sehingga memungkinkan manajemen untuk tidak memaksimalkan kinerjanya dalam perusahaan sehingga tidak mempengaruhi terjadinya kejahatan keuangan korporasi dalam perusahaan.

\section{REFERENSI}

Abdullah, W. N., \& Said, R. (2018). The influence of corporate governance and human governance towards corporate financial crime: A conceptual paper. Developments in Corporate Governance and Responsibility, 13, 193-215. https://doi.org/10.1108/S2043-052320180000013014

Abdullah, W. N., \& Said, R. (2019). Audit and risk committee in financial crime prevention. Journal of Financial Crime, 26(1), 223-234. https://doi.org/10.1108/JFC-11-2017-0116

Abdullah, W. N., Said, R., \& Caliyurt, K. (2019). The Effect of Internal Governance on Corporate Financial Crime of Companies in Malaysia. Journal of Governance and Integrity.

ACFE. (2019). Survei Fraud Indonesia. Association of Certified Fraud Examiners, 1-76.

Aghghaleh, S. F., Iskandar, T. M., \& Mohamed, Z. M. (2014). Fraud Risk Factors of Fraud Triangle and the Likelihood of Fraud Occurrence: Evidence from Malaysia. Information Management and Business Review, 6(1), 1-7. https://doi.org/10.22610/imbr.v6i1.1095 
Arifin, B., Nofianti, N., \& Kautsar, H. F. (2016). Pengaruh Likuiditas, Solvabilitas, Profitabilitas, Nilai Pasar, Dan Pemanfaatan Aset Terhadap Financial Statement Fraud. Tirtayasa Ekonomika, 11(2), 255. https://doi.org/10.35448/jte.v11i2.4243

Bhuiyan, M. B. U., Cheema, M. A., \& Man, Y. (2020). Risk committee, corporate risk-taking and firm value. Managerial Finance. https://doi.org/10.1108/MF-07-2019-0322

Dewi, S. (2019). Pengaruh Mekanise Corporate Governance terhadap Kemungkinan Terjadinya Fraud (Studi Empiris pada Perusahaan PERBANKAN yang Terdaftar di Bursa Efek Indonesia). BENEFIT Jurnal Manajemen Dan Bisnis, 4(2), 179-188.

Dimitrijevic, D., Jovkovic, B., \& Milutinovic, S. (2020). The scope and limitations of external audit in detecting frauds in company's operations. Journal of Financial Crime. https://doi.org/10.1108/JFC-11-2019-0155

Ferdinand, R., \& Santosa, S. (2019). Factors that Influence Fraudulent Financial Statements in Retail Companies - Indonesia. JAAF (Journal of Applied Accounting and Finance), 2(2), 99. https://doi.org/10.33021/jaaf.v2i2.548

Handoko, B. L., \& Ramadhani, K. A. (2017). Pengaruh Karakteristik Komite Audit, Keahlian Keuangan, dan Ukuran Perusahaan terhadap Kemungkinan Kecurangan Laporan Keuangan. DeReMa Jurnal Manajemen, 12(1).

Hanifa, S. I., \& Laksito, H. (2015). Pengaruh Fraud Indicators Terhadap Fraudulent Financial Statement: Studi Empiris Pada Perusahaan Yang Listed Di Bursa Efek Indonesia (Bei) Tahun 2008-2013. Diponegoro Journal of Accounting, 4(4), 411-425.

Hari Prayoga, M., Purwanti, D., \& euangan Negara STAN, P. K. (2020). CASE ANALYSIS OF REVENUE RECOGNITION FRAUD OF PT GARUDA INDONESIA (PERSERO) Tbk IN 2018 (Vol. 2, Issue 2).

Hidayatun, F., \& Juliarto, A. (2019). Fraud Triangle Dan Fraud Diamond Model Dalam Prediksi Kecurangan Laporan Keuangan. Diponegoro Journal of Accounting, 8(4), 1-8.

Ismiyanti, F., \& Prastichia, C. (2015). Mekanisme Corporate Governance dan Kecurangan Laporan Keuangan. In DeReMa (Development Research of Management) Jurnal Manajemen (Vol. 10, Issue 2, pp. 200-226). https://doi.org/10.19166/derema.v10i2.171

Iswati, D., Nindito, M., \& Zakaria, A. (2017). The Effect of Internal Financial Indicators on the Tendency of Account- ing Fraud (A Case of Companies Listed in Indonesia Stock Exchange). Jurnal Dinamika Akuntansi, 9(2), 123-131.

Junnestine, \& Christian, N. (2021). ANALISIS REVENUE SHENANIGANS PADA PERUSAHAAN PT GARUDA INDONESIA (PERSERO) Tbk. PROGRESS, 4(2).

Kamolsakulchai, M. (2015). The Impact of the Audit Committee Effectiveness and Audit Quality on Financial Reporting Quality of listed company in Stocks Exchange of Thailand. Bus. Econ. Res.Online, 4(2), 2304-1013.

Mardianto, M., \& Tiono, C. (2019). Analisis Pengaruh Fraud Triangle Dalam Mendeteksi Kecurangan Laporan Keuangan. Jurnal Benefita, 1(1), 87. https://doi.org/10.22216/jbe.v1i1.3349

Martantya, \& Daljono. (2013). Melalui Faktor Risiko Tekanan Dan Peluang. Diponegoro Journal of Accounting, 2(2), 1-12.

Nila Sari, P., \& Husadha, C. (2020). PENGUNGKAPAN CORPORATE GOVERNANCE TERHADAP INDIKASI FRAUD DALAM PELAPORAN KEUANGAN. Jurnal Ilmiah Akuntansi Dan Manajemen (JIAM), 16(1).

Nugroho, A. A., Baridwan, Z., \& Mardiati, E. (2018). Pengaruh Profitabilitas, Likuiditas, Leverage, dan Corpo-Rate Governance Terhadap Kecurangan Laporan Keuangan, Serta Financial Distress $\begin{array}{llllll}\text { Sebagai Variabel Intervening. } & \text { Media }\end{array}$ https://doi.org/10.21107/mediatrend.v13i2.4065

Nurliasari, K. E., \& Achmad, T. (2020). Pengaruh Karakteristik Komite Audit Dan Perusahaan Terhadap Kecurangan Pelaporan Keuangan. Diponegoro Journal of Accounting, 9(1), 1-12. https://doi.org/10.14710/jaa.11.1.1-24

Prasetyo, A. B. (2014). Pengaruh Karakteristik Komite Audit, Perusahaan dan Struktur Kepemilikan Terhadap Kecurangan Pelaporan Keuangan. Journal of Accounting and Business, 11(1). https://doi.org/10.20884/1.sar.2016.1.2.304 
Priswita, F., \& Taqwa, S. (2019). Pengaruh corporate governance terhadap kecurangan laporan keuangan. Jurnal Eksplorasi Akuntansi, 1(4), 1705-1722. http://jea.ppj.unp.ac.id/index.php/jea/issue/view/14\%0D

Riyanti, E. C., W Putri, H. C., Artadi, W., \& Umar, H. (2019). PENGARUH KUALITAS AUDIT TERHADAP FRAUDULENT FINANCIAL REPORTING DENGAN KOMITE AUDIT SEBAGAI VARIABEL MODERASI (Studi Empiris Pada Perusahaan Manufaktur yang terdaftar di BEI tahun 2016 - 2018). Prosiding Seminar Nasional Cendekiawan, 2016, 2. https://doi.org/10.25105/semnas.v0i0.5774

Ruchiatna, G., Puspa Midiastuty, P., \& Suranta, E. (2020). Pengaruh karakteristik komite audit terhadap fraudulent financial reporting. Jurnal Akuntansi, Keuangan, Dan Manajemen, 1(4), 255-264. https://doi.org/10.35912/jakman.v1i4.52

Rusmana, O., \& Tanjung, H. (2019). Identifikasi Kecurangan Laporan Keuangan Dengan Fraud Pentagon Studi Empiris Bumn Terdaftar Di Bursa Efek Indonesia. Jurnal Ekonomi, Bisnis, Dan Akuntansi, 21, 1-15. http://www.jp.feb.unsoed.ac.id/index.php/jeba/article/view/1545

Siswanto, N., \& Soedharto, J. (2017). THE IMPACT OF AUDIT COMMITTEE CHARACTERISTICS ON FINANCIAL DISTRESS. DIPONEGORO JOURNAL OF ACCOUNTING, 6(2), 1-9. http://ejournal-s1.undip.ac.id/index.php/accounting

Tiapandewi, Y., Suryandari, A., \& Arie, B. (2020). Dampak Fraud Triangle ... JURNAL KHARISMA, 2 No.2, 156-173.

Utomo, S. D., Machmuddah, Z., \& Pamungkas, I. D. (2019). The effect of auditor switching and managerial ownership on fraudulent financial statement. WSEAS Transactions on Business and Economics, 16, 306-315.

Vivianita, A., \& Indudewi, D. (2019). Financial Statement Fraud Pada Perusahaan Pertambangan Yang Dipengaruhi Oleh Fraud Pentagon Theory (Studi Kasus Di Perusahaan Tambang Yang Terdaftar Di Bei Tahun 2014-2016). Jurnal Dinamika Sosial Budaya, 20(1), 1. https://doi.org/10.26623/jdsb.v20i1.1229

Wahyu Vitaningsih, T. A., Budiwibowo, S., \& Astuti, E. (2020a). Studi Kasus Penerapan PSAK 23 dalam Pengakuan Pendapatan pada PT G. E-Jurnal Akuntansi, 30(4), 840. https://doi.org/10.24843/eja.2020.v30.i04.p03

Wahyu Vitaningsih, T. A., Budiwibowo, S., \& Astuti, E. (2020b). Studi Kasus Penerapan PSAK 23 dalam Pengakuan Pendapatan pada PT G. E-Jurnal Akuntansi, 30(4), 840. https://doi.org/10.24843/eja.2020.v30.i04.p03

Wicaksono, G. S., \& Chariri, A. (2015). Mekanisme Corporate Governance Dan Kemungkinan Kecurangan Dalam Pelaporan Keuangan. Diponegoro Journal of Accounting, 4(4), 552-563.

Zager, L., Malis, S. S., \& Novak, A. (2016). The Role and Responsibility of Auditors in Prevention and Detection of Fraudulent Financial Reporting. Procedia Economics and Finance, 39(November 2015), 693-700. https://doi.org/10.1016/s2212-5671(16)30291-x 